\title{
Pelatihan Pembuatan Japanese Fruit Sando di SML UMKM Centre BSD City
}

\author{
Vasco A. H. Goeltom, V. Nonot Yuliantoro, Dhana Calista Oktaviani*, Jesslyn Angriawan \\ Universitas Pelita Harapan, Tangerang, Indonesia \\ *dhanacalista510@gmail.com
}

\section{Informasi Artikel}

Dikirim: 14 Desember 2021

Diterima: 22 Desember 2021

Dipublikasi: 23 Desember 2021

Keywords:

Street Food, East Asia,

Japanese Fruit Sando

\begin{abstract}
The East Asian region consists of China, Taiwan, Korea, Japan, and Mongolia. By all mean, the food originating from each country is very diverse and is experiencing an increasing trend in recent years. In that area, of course, has a typical and varied street food. Snack food or what is commonly referred to as "Street Food" is food or drink served in containers in public places and has various variants and types. However, in the current era of the Covid-19 pandemic, connoisseurs of street food must also be more careful in consuming food from outside. Therefore, the author organizes community service (PKM) with the theme "Training for Making Japanese Fruit Sando at SML UMKM Center BSD City" which is one of the street foods from Japan so that you can make and create your own at home.
\end{abstract}

\section{Abstrak}

Kawasan Asia Timur terdiri dari China, Taiwan, Korea, Jepang dan Mongolia. Tentunya makanan yang berasal dari negara masing-masing sangatlah beragam dan sedang mengalami peningkatan tren di beberapa tahun terakhir. Di Kawasan itu juga tentunya memiliki makanan jajanan yang khas dan juga bervariasi. Makanan jajanan atau yang biasa disebut dengan "Street Food" merupakan makanan atau minuman yang disajikan dalam wadah di tempat umum ini memiliki berbagai macam varian dan jenisnya. Namun pada era pandemic Covid-19 sekarang ini, para penikmat dari street food ini pun harus lebih berhati-hati dalam mengonsumsi makanan dari luar. Maka dari itu penulis menyelenggarakan pengabdian kepada masyarakat (PKM) dengan tema "Pelatihan Pembuatan Japanese Fruit Sando di SML UMKM Centre BSD City" yang merupakan salah satu street food dari Jepang agar dapat dibuat dan dikreasikan sendiri di rumah. 


\section{PENDAHULUAN}

Makanan merupakan suatu kebutuhan fisiologis. Pangan adalah segala sesuatu yang berasal dari sumber hayati dan air, baik yang diolah maupun tidak diolah yang diperuntukkan sebagai makanan atau minuman bagi konsumsi manusia (Daliwu et al, 2021). Kuliner secara umum adalah kegiatan yang berhubungan dengan memasak yang berkaitan erat dengan konsumsi makanan sehari-hari. Dalam perkembangannya, digunakan untuk berbagai macam kegiatan maupun seni kuliner, seperti seni persiapan, memasak dan penyajian makanan, biasanya dalam bentuk makanan. Wisata kuliner merupakan perpaduan menikmati suatu makanan sambil menikmati suasana, bersantai, sehingga memanfaatkan waktu ke tempat yang menyediakan makanan khas (Febriana \& Herlambang, 2020). Makanan Asia cenderung lebih kompleks dalam hal rasa dan proses pembuatannya, serta makanan Asia menggunakan berbagai bumbu dan rempah-rempah tradisional sehingga membuat makanan Asia cenderung lebih diminati. Kuliner di Asia juga memiliki ciri khas masakan nya di tiap negara contohnya seperti China yaitu makanan yang diolah dengan cepat dan api panas, mudah dikerjakan hanya perlu persiapan memotong sayuran dan bumbu, perlu waktu lebih dulu, tidak terlalu rumit pemasakannya (Nur Biduri et al., 2020).

Makanan jajanan (street food) sudah menjadi makanan sehari-hari bagi kehidupan masyarakat. Makanan jajanan seperti ini menjadi pusat kuliner yang cukup populer karena harga nya yang murah dan aksesibilitas makanan yang mudah sehingga bagi masyarakat, jenis makanan jajanan ini merupakan salah satu sumber pendapatan mereka. Tidak hanya berkontribusi pada produksi dan distribusi, makanan jajanan juga berkontribusi kepada ekonomi di seluruh negara secara keseluruhan. Maka dari itu, kuliner makanan jajanan ini banyak dikonsumsi oleh seluruh orang di negara berkembang (Aykaç \& Buyruk, 2021).

Pada umumnya yang menikmati kuliner makanan jajanan di pinggiran ini adalah para pendatang dari negara lain. Tujuan dari para wisatawan yaitu untuk mencicipi serta mengetahui makanan dan minuman khas dari suatu negara tersebut yang memiliki cita rasa yang berbeda dari cara penyajian, cara memasak dan waktu penyajiannya. Keunikan seperti inilah yang menarik para masyarakat serta wisatawan untuk membeli makanan jajanan yang dijual di pinggiran (Prabandari et al., 2020).

Jenis makanan jajanan yang dijual di pinggiran memiliki daya tarik dan kepuasannya tersendiri. Makanan jajanan seperti ini pada umumnya ber alokasi disuatu tempat untuk berjualan. Tujuan dari dibuatnya lokasi tersendiri untuk berjualan makanan jajanan yaitu agar mempermudah masyarakat ataupun para wisatawan untuk menemukan tempat makanan jajanan yang mereka inginkan. Salah satu pusat makanan jajanan yang sangat popular adalah di negara Asia tepatnya di China. Banyak makanan jajanan yang dijual di pasar malam yang merupakan suatu ciri khas dari negara tersebut. Ciri khas ini lah yang dapat menjadi daya tarik bagi penduduk kota dari negara lain untuk datang mencicipi makanan yang sedang populer dari negara yang di datangi nya. Bagi penduduk china sebagian besar makanan utama mereka yaitu makanan-makanan jajanan karena dengan harga yang murah, penduduk di china bisa mendapatkan makanan yang sesuai dengan budget mereka (Steven \& Carolina, 2018).

Dengan seiring berjalannya waktu, seluruh dunia sudah terpapar oleh virus Covid-19 yang membuat ekonomi para pedagang menjadi menurun di karenakan masyarakat takut untuk makan jajanan diluar untuk mencegah virus semakin menyebar dan masyarakat pun menghindari terpaparnya virus Covid-19 (Zeb et al., 2021). Penyebaran virus covid-19 ini dapat berpindah dari manusia ke manusia itu sendiri, dari barang-barang yang mereka pegang maupun dari makanan yang mereka makan. Covid19 merupakan virus yang gampang menyebar dari orang ke orang lain sehingga para 
konsumen yang ingin makan di tempat terbuka seperti di pinggiran (street food) merasa takut karena tidak ingin terpapar oleh virus tersebut.

Dengan begitu, ada beberapa cara agar mencegah penyebaran virus Covid-19 dari pedagang kepada konsumen yaitu membersihkan tangan yang baik, menggunakan sarung tangan, menggunakan hand sanitaiser, face shield dan mengatur jarak antar pembeli (Wijanarko, 2020) Cara lain untuk pencegahan virus Covid-19 yaitu dengan take-out atau dengan cara membungkus makanan yang mereka inginkan lalu dibawa pulang ke rumah sehingga mereka lebih leluasa untuk makan makanan yang mereka minati tanpa rasa takut terpapar dengan virus Covid-19. Maka kepatuhan terhadap kebersihan pribadi yang baik dan penanganan makanan yang aman merupakan salah satu cara yang efektif untuk mencegah penularan penyakit yang dapat berpindah dari penjual kepada konsumen (Ranka, 2020).

PKM memiliki kepanjangan dari Pengabdian Kepada Masyarakat yang merupakan suatu kegiatan yang diikuti oleh mahasiswa untuk berpartisipasi langsung dalam kegiatan kemasyarakatan. Menurut Undang-undang no. 20 tahun 2003 mengenai sistem Pendidikan nasional, pasal 20 mengatakan bahwa perguruan tinggi memiliki kewajiban untuk mengadakan penelitian dan pengabdian kepada masyarakat disamping melaksanakan Pendidikan.

Maka dari itu penulis ingin menyelenggarakan kegiatan kemasyarakatan ini dengan mengadakan pengabdian kepada masyarakat dengan mengambil fokus untuk melatih cara pembuatan dari salah satu street food yang berasal dari kawasan Asia Timur yaitu Jepang. Makanan tersebut adalah Japanese Fruit Sando yang merupakan sandwich yang didalamnya di isi dengan krim kocok atau yang biasa disebut Whipped Cream serta stroberi segar. Makanan ini merupakan jajanan yang bergizi dan tentunya juga lezat. (Santa, 2021).

\section{METODE PELAKSANAAN KEGIATAN}

Workshop pelatihan pembuatan Japanese Fruit Sando di SML UMKM Centre BSD City diadakan pada tanggal 1 Desember 2021 dengan jumlah peserta sebanyak 15 orang yang dilaksanakan secara online melalui aplikasi zoom pada pukul 14:00 WIB hingga pukul 15:00 WIB.

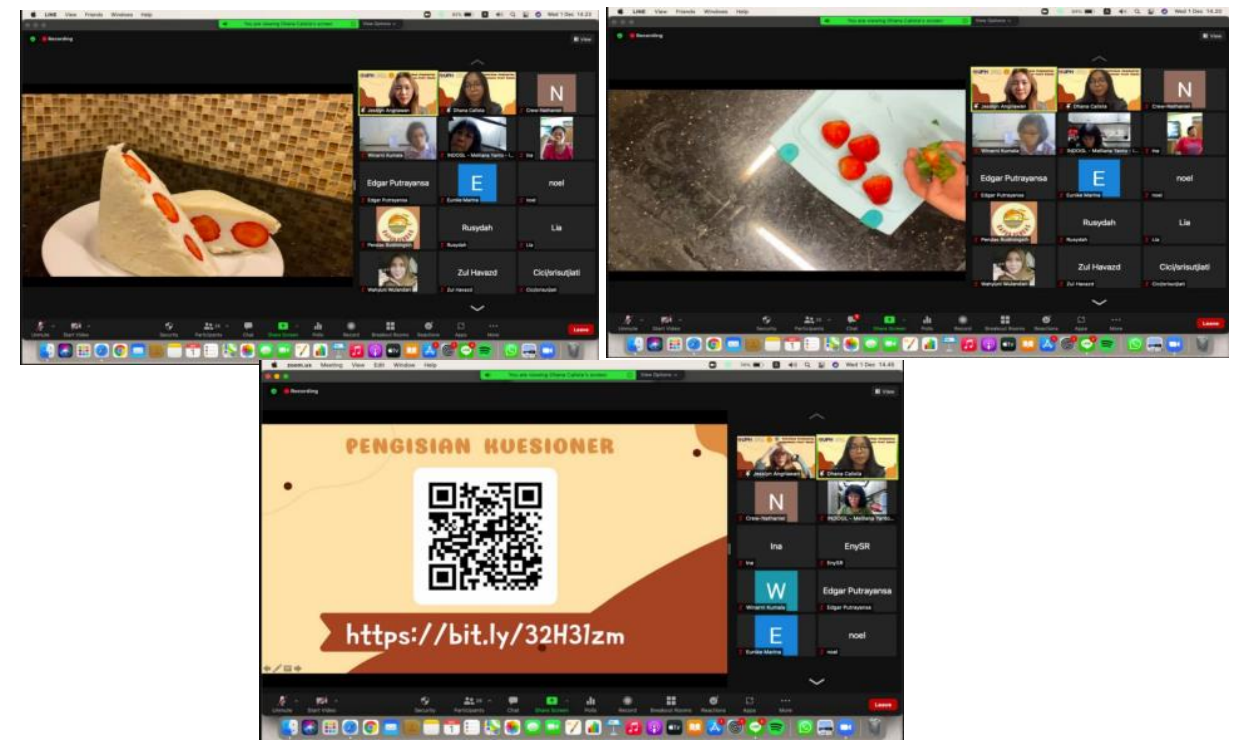

Gambar 1. Zoom Online Pengabdian asyarakat 
Pada pukul 14:00 WIB peserta dipersilahkan masuk ke aplikasi zoom, dilanjutkan dengan kata pembuka dan kata sambutan dari Ketua Tim Pelaksana. Tim Pengabdian Kepada Masyarakat akan mempresentasikan materi power point kemudian menyajikan video bagaimana cara pembuatan dari Japanese Fruit Sando yang telah dibuat sebelumnya. Sebelum tim Pengabdian Kepada Masyarakat menayangkan video tersebut, tim pelaksana memberikan link form pre-test dan pada saat pemutaran video sudah selesai tim pelaksana memberikan kembali link form post-test. Pada saat video berlangsung, para peserta akan mencontoh produk pada saat zoom berlangsung. Kemudian tim pelaksana juga akan mempersiapkan form atau kuesioner online yang akan dibagian diakhir acara untuk melihat apakah menurut peserta acara pelatihan ini sudah terlaksana dengan baik.

Setelah itu akan dilanjutkan dengan sesi tanya jawab untuk para peserta untuk menguji pemahaman dan hal-hal yang sekira nya belum jelas. Acara workshop ditutup dengan foto Bersama dan ucapan terima kasih. Berikut ini adalah susunan acara dalam bentuk time table:

Tabel 1. Time Table

\begin{tabular}{c|c|c|l}
\hline No & Waktu & Durasi & Kegiatan \\
\hline 1 & $13: 45-13: 50$ & 5 & Absen masuk ke zoom \\
\hline 2 & $13.50-14.00$ & $10^{\prime}$ & Peserta mengerjakan Pre Test \\
\hline 3 & $14: 00-14: 10$ & 10 & Pembukaan Oleh MC \\
\hline 4 & $14: 10-14: 15$ & 5 & Sambutan dari Dosen Pembimbing \\
\hline 5 & $14: 15-14: 25$ & 10 & Pemaparan Materi \\
\hline 6 & $14: 25-14: 35$ & 10 & Pemutaran Video Materi \\
\hline 7 & $14: 35-14: 40$ & 5 & Sesi tanya jawab \\
\hline 8 & $14: 40-15: 10$ & 30 & Pembuatan Japanese Fruit Sando \\
\hline 9 & $15: 10-15: 25$ & 15, & Pengisian Survey dan Foto Bersama \\
\hline 10 & $15: 25-15: 30$ & 5, & Closing Acara \\
\hline
\end{tabular}

\section{HASIL PEMBAHASAN}

Dari Pre-Test dan Post Test yang sudah dibagikan kepada peserta SML UMKM Centre, berikut adalah hasil kuesioner :

\section{Tentang Street Food}

Tabel 2. Pre-Test dan Post-Test

\begin{tabular}{|c|c|c|c|c|c|}
\hline \multirow[t]{3}{*}{ Pertanyaan } & \multirow[t]{3}{*}{ Jawaban } & \multicolumn{2}{|c|}{ Pre-Test } & \multicolumn{2}{|c|}{ Post-Test } \\
\hline & & Jumlah & Persentase & Jumlah & Persentase \\
\hline & & Responden & & Responden & \\
\hline \multirow{4}{*}{$\begin{array}{l}\text { Apa } \\
\text { Street } \\
\text { Food? }\end{array}$} & Makanan Utama & 0 & $0 \%$ & 0 & $0 \%$ \\
\hline & Makanan Penutup & 0 & $0 \%$ & 0 & $0 \%$ \\
\hline & Makanan Pembuka & 0 & $0 \%$ & 0 & $0 \%$ \\
\hline & Makanan Jajanan & 15 & $100 \%$ & 15 & $100 \%$ \\
\hline
\end{tabular}

Berdasarkan tabel diatas, dapat dilihat bahwa pada pre-test $100 \%$ peserta menjawab "Makanan Jajanan". Kemudian setelah diberikan pemaparan materi, sebanyak 100\% peserta tetap menjawab dengan benar yaitu "Makanan Jajanan". Panitia telah mempersiapkan materi yang mudah dipahami dan lengkap sehingga para peserta bisa menjawab pertanyaan dengan benar sesudah pemaparan materi berlangsung. 


\section{Komponen Utama dari Produk Japanese Fruit Sando}

Tabel 3. Pre-Test dan Post-Test

\begin{tabular}{|c|c|c|c|c|c|}
\hline \multirow[t]{2}{*}{ Pertanyaan } & \multirow[t]{2}{*}{ Jawaban } & \multicolumn{2}{|c|}{ Pre-Test } & \multicolumn{2}{|c|}{ Post-Test } \\
\hline & & $\begin{array}{c}\text { Jumlah } \\
\text { Responden }\end{array}$ & Persentase & $\begin{array}{c}\text { Jumlah } \\
\text { Responden }\end{array}$ & Persentase \\
\hline \multirow{4}{*}{$\begin{array}{l}\text { Apa komponen } \\
\text { utama dari } \\
\text { produk Japanese } \\
\text { Fruit Sando }\end{array}$} & $\begin{array}{l}\text { Roti, stroberi, } \\
\text { whipped cream }\end{array}$ & 10 & $66,7 \%$ & 15 & $100 \%$ \\
\hline & $\begin{array}{l}\text { Roti, selai, whipped } \\
\text { cream }\end{array}$ & 1 & $6,7 \%$ & 0 & $0 \%$ \\
\hline & Stroberi, selai, roti & 3 & $20 \%$ & 0 & $0 \%$ \\
\hline & Mentega, selai, roti & 1 & $6,7 \%$ & 0 & $0 \%$ \\
\hline
\end{tabular}

Berdasarkan tabel diatas, dapat dilihat bahwa pada pre-test $66,7 \%$ peserta menjawab "roti, stroberi, whipped cream" kemudian sebanyak $20 \%$ peserta menjawab "mentega, selai, roti" lalu ada sebanyak $6,7 \%$ peserta menjawab "roti, selai, whipped cream" dan juga "stroberi, selai, roti. Sedangkan setelah diberikan pemaparan materi, sebanyak $100 \%$ peserta tetap menjawab dengan benar yaitu "roti, stroberi, whipped cream". Dengan begitu, panitia telah mempersiapkan materi yang mudah dipahami dan lengkap sehingga para peserta bisa menjawab pertanyaan dengan benar sesudah pemaparan materi berlangsung.

\section{Buah Stoberi Diganti Dengan Buah Lain}

Tabel 4. Pre-Test dan Post-Test

\begin{tabular}{lccccc}
\hline \multirow{2}{*}{ Pertanyaan } & Jawaban & \multicolumn{2}{c}{ Pre-Test } & \multicolumn{2}{c}{ Post-Test } \\
\cline { 3 - 6 } & & $\begin{array}{c}\text { Jumlah } \\
\text { Responden }\end{array}$ & Persentase & $\begin{array}{c}\text { Jumlah } \\
\text { Responden }\end{array}$ & Persentase \\
\hline $\begin{array}{l}\text { Apa buah stroberi dapat } \\
\text { diganti dengan buah }\end{array}$ & Ya & 11 & $73,3 \%$ & 14 & $93,3 \%$ \\
\cline { 3 - 6 } lain? & Tidak & 4 & $26,7 \%$ & 1 & $6,7 \%$ \\
\hline
\end{tabular}

Berdasarkan tabel diatas, dapat dilihat bahwa pada pre-test sebanyak $73,3 \%$ peserta menjawab "ya" kemudian sebanyak 26,7\% peserta menjawab "tidak". Sedangkan setelah diberikan pemaparan materi, sebanyak 93,3\% peserta menjawab "ya" selebihnya sebanyak 6,7\% peserta menjawab "tidak". Dengan begitu, panitia telah mempersiapkan materi yang mudah dipahami dan lengkap sehingga para peserta bisa menjawab pertanyaan dengan benar sesudah pemaparan materi berlangsung.

\section{Lamanya Untuk Mengocok Whipped Cream}

Tabel 5. Pre-Test dan Post-Test

\begin{tabular}{lccccc}
\hline \multicolumn{1}{c}{ Pertanyaan } & Jawaban & \multicolumn{2}{c}{ Pre-Test } & \multicolumn{2}{c}{ Post-Test } \\
\cline { 2 - 6 } & & $\begin{array}{c}\text { Jumlah } \\
\text { Responden }\end{array}$ & Persentase & $\begin{array}{c}\text { Jumlah } \\
\text { Responden }\end{array}$ & Persentase \\
\hline Butuh berapa lama & 3 menit & 7 & $46,7 \%$ & 12 & $80 \%$ \\
untuk mengocok & 1 menit & 1 & $6,7 \%$ & 1 & $6,7 \%$ \\
\cline { 2 - 6 } Whipped Cream? & 5 menit & 5 & $33,3 \%$ & 2 & $13,3 \%$ \\
\cline { 2 - 6 } & 2 menit & 2 & $13,3 \%$ & 0 & $0 \%$ \\
\hline
\end{tabular}


Berdasarkan tabel diatas, dapat dilihat bahwa pada pre-test $46,7 \%$ peserta menjawab "3 menit" kemudian sebanyak 33,3\% peserta menjawab "5 menit" lalu ada sebanyak 13,3\% peserta menjawab " 2 menit" dan untuk pilihan jawaban yang terakhir yaitu sebanyak $6,7 \%$ peserta menjawab "1 menit". Sedangkan setelah diberikan pemaparan materi, sebanyak $80 \%$ peserta menjawab dengan benar yaitu "3 menit", namun sebanyak 13,3\% peserta menjawab "5 menit". Dengan begitu, panitia telah mempersiapkan materi yang mudah dipahami dan lengkap sehingga para peserta bisa menjawab pertanyaan dengan benar sesudah pemaparan materi berlangsung.

\section{Komponen Utama Dari Whipped Cream}

Tabel 6. Pre-Test dan Post-Test

\begin{tabular}{lllccc}
\hline Pertanyaan & Jawaban & Pre-Test & \multicolumn{3}{c}{ Post-Test } \\
\cline { 2 - 6 } & & $\begin{array}{l}\text { Jumlah } \\
\text { Responden }\end{array}$ & Persentase & $\begin{array}{l}\text { Jumlah } \\
\text { Responden }\end{array}$ & Persentase \\
\hline \multirow{3}{*}{$\begin{array}{l}\text { Apa komponen } \\
\text { dari Whipped Cream }\end{array}$} & Santan & 0 & $0 \%$ & 0 & $0 \%$ \\
\cline { 2 - 6 } & Mentega & 1 & $6,7 \%$ & 3 & $20 \%$ \\
\cline { 2 - 6 } & Gula & 8 & $53,3 \%$ & 1 & $6,7 \%$ \\
\cline { 2 - 7 } & Susu sapi & 6 & $40 \%$ & 11 & $73,3 \%$ \\
\hline
\end{tabular}

Berdasarkan tabel diatas, dapat dilihat bahwa pada pre-test $53,3 \%$ peserta menjawab "gula" kemudian sebanyak $40 \%$ peserta menjawab "susu sapi" lalu ada sebanyak 6,7\% peserta menjawab "mentega". Sedangkan setelah diberikan pemaparan materi, sebanyak 73,3\% peserta menjawab dengan benar yaitu "susu sapi", namun sebanyak 20\% peserta menjawab "mentega" serta sebanyak 6,7\% peserta menjawab "gula". Dengan begitu, panitia telah mempersiapkan materi yang mudah dipahami dan lengkap sehingga para peserta bisa menjawab pertanyaan dengan benar sesudah pemaparan materi berlangsung.

\section{Khasiat Dari Buah Stroberi}

Tabel 7. Pre-Test dan Post-Test

\begin{tabular}{|c|c|c|c|c|c|}
\hline \multirow[t]{2}{*}{ Pertanyaan } & \multirow[t]{2}{*}{ Jawaban } & \multicolumn{2}{|c|}{ Pre-Test } & \multicolumn{2}{|c|}{ Post-Test } \\
\hline & & $\begin{array}{l}\text { Jumlah } \\
\text { Responden }\end{array}$ & Persentase & $\begin{array}{l}\text { Jumlah } \\
\text { Responden }\end{array}$ & Persentase \\
\hline \multirow{4}{*}{$\begin{array}{l}\text { Apa khasiat } \\
\text { dari buah } \\
\text { stroberi? }\end{array}$} & Menambah stamina & 1 & $6,7 \%$ & 3 & $20 \%$ \\
\hline & Mengurangi lemak & 3 & $20 \%$ & 2 & $13,3 \%$ \\
\hline & $\begin{array}{l}\text { Meningkatkan } \\
\text { kekebalan tubuh }\end{array}$ & 7 & $46,7 \%$ & 9 & $60 \%$ \\
\hline & $\begin{array}{l}\text { Mencegah tekanan } \\
\text { darah rendah }\end{array}$ & 4 & $26,7 \%$ & 1 & $6,7 \%$ \\
\hline
\end{tabular}

Berdasarkan tabel diatas, dapat dilihat bahwa pada pre-test $46,7 \%$ peserta menjawab "meningkatkan kekebalan tubuh" kemudian sebanyak 26,7\% peserta menjawab "mencegah tekanan darah rendah" lalu ada sebanyak $20 \%$ peserta menjawab "mengurangi lemak" dan untuk pilihan jawaban yang terakhir yaitu sebanyak 6,7\% peserta menjawab "menambah stamina". Sedangkan setelah diberikan pemaparan 
materi, sebanyak $60 \%$ peserta menjawab dengan benar yaitu "meningkatkan kekebalan tubuh", namun sebanyak $20 \%$ peserta menjawab "menambah stamina", kemudian sebanyak 13,3\% menjawab "mengurangi lemak" serta sebanyak 6,7\% peserta menjawab "mencegah tekanan darah rendah". Dengan begitu, panitia telah mempersiapkan materi yang mudah dipahami dan lengkap sehingga para peserta bisa menjawab pertanyaan dengan benar sesudah pemaparan materi berlangsung.

\section{Alat Yang Digunakan Selain Hand Mixer Untuk Mengocok Whipped Cream}

Tabel 8. Pre-test dan Post-test

\begin{tabular}{lllccc}
\hline \multirow{2}{*}{ Pertanyaan } & \multicolumn{1}{c}{ Jawaban } & \multicolumn{2}{c}{ Pre-Test } & \multicolumn{2}{c}{ Post-Test } \\
\cline { 3 - 6 } & & $\begin{array}{c}\text { Jumlah } \\
\text { Responden }\end{array}$ & Persentase & $\begin{array}{c}\text { Jumlah } \\
\text { Responden }\end{array}$ & Persentase \\
\hline $\begin{array}{l}\text { Apa alat yang digunakan } \\
\text { selain Hand Mixer untuk } \\
\text { mengocok Whipped }\end{array}$ & Sendok & 2 & $13,3 \%$ & 1 & $6,7 \%$ \\
\cline { 2 - 6 } Cream & Garpu & 1 & $6,7 \%$ & 2 & $13,3 \%$ \\
\cline { 2 - 7 } & Balloon Whisk & 4 & $26,7 \%$ & 4 & $26,7 \%$ \\
\cline { 2 - 7 } & Semua benar & 8 & $53,3 \%$ & 8 & $53,3 \%$ \\
\hline
\end{tabular}

Berdasarkan tabel diatas, dapat dilihat bahwa pada pre-test $53,3 \%$ peserta menjawab "semua benar" kemudian sebanyak 26,7\% peserta menjawab "Balloon Whisk" lalu ada sebanyak 13,3\% peserta menjawab "sendok" dan untuk pilihan jawaban yang terakhir yaitu sebanyak 6,7\% peserta menjawab "garpu". Sedangkan setelah diberikan pemaparan materi, sebanyak $53,3 \%$ peserta menjawab dengan benar yaitu "semua benar", namun sebanyak 26,7\% peserta menjawab "Balloon Whisk", kemudian sebanyak 13,3\% menjawab "garpu" serta sebanyak 6,7\% peserta menjawab "sendok". Dengan begitu, panitia telah mempersiapkan materi yang mudah dipahami dan lengkap sehingga para peserta bisa menjawab pertanyaan dengan benar sesudah pemaparan materi berlangsung. Berikut adalah hasil feedback form yang dikirimkan dan diisi oleh para peserta SML UMKM Centre.

\section{Kegiatan Workshop sudah terorganisir dengan baik}

Tabel 9. Feedback Form

\begin{tabular}{lllc}
\hline \multicolumn{1}{c}{ Pertanyaan } & \multicolumn{1}{c}{ Jawaban } & Jumlah Responden & Persentase \\
\hline \multirow{4}{*}{$\begin{array}{l}\text { Kegiatan } \\
\text { terorganisir dengan baik }\end{array}$} & Sangat Tidak Setuju & 0 & $0 \%$ \\
\cline { 2 - 4 } & Tidak Setuju & 0 & $0 \%$ \\
\cline { 2 - 4 } & Kurang Setuju & 1 & $6,7 \%$ \\
\cline { 2 - 4 } & Agak Setuju & 0 & $0 \%$ \\
\cline { 2 - 4 } & Setuju & 2 & $13,3 \%$ \\
\cline { 2 - 4 } & Sangat Setuju & 12 & $80 \%$ \\
\hline
\end{tabular}

Hasil dari pertanyaan tersebut menunjukkan 12 orang atau setara dengan $80 \%$ menjawab sangat setuju, 2 orang atau setara dengan $13.3 \%$ menjawab setuju, dan 1 orang atau setara dengan $6.7 \%$ menjawab cenderung tidak setuju. 
DOI: https://doi.org/10.30647/jpp.v30647/jpp.v3i2.1595

Vasco A. H. Goeltom, V. Nonot Yuliantoro, Dhana Calista Oktaviani dan Jesslyn Angriawan

\section{Materi Yang Disampaikan Bermanfaat Bagi Peserta}

Tabel 10. Feedback Form

\begin{tabular}{|c|c|c|c|c|}
\hline \multicolumn{2}{|c|}{ Pertanyaan } & Jawaban & Jumlah Responden & Persentase \\
\hline \multirow{6}{*}{$\begin{array}{l}\text { Materi } \\
\text { disampaikan } \\
\text { bermanfaat } \\
\text { peserta }\end{array}$} & \multirow[t]{2}{*}{ yang } & Sangat Tidak Setuju & 0 & $0 \%$ \\
\hline & & Tidak Setuju & 0 & $0 \%$ \\
\hline & \multirow[t]{4}{*}{ bagi } & Kurang Setuju & 0 & $0 \%$ \\
\hline & & Agak Setuju & 1 & $6,7 \%$ \\
\hline & & Setuju & 3 & $20 \%$ \\
\hline & & Sangat Setuju & 11 & $73,3 \%$ \\
\hline
\end{tabular}

Hasil dari pertanyaan tersebut menunjukkan menunjukkan 11 orang atau setara dengan $73.3 \%$ menjawab sangat setuju, 3 orang atau setara dengan $20 \%$ menjawab setuju dan 1 orang atau setara dengan $6.7 \%$ menjawab cenderung setuju.

\section{Mengerti Bagaimana Cara Membuat Japanese Fruit Sando}

Tabel 11. Feedback Form

\begin{tabular}{|c|c|c|c|}
\hline Pertanyaan & Jawaban & Jumlah Responden & Persentase \\
\hline \multirow{6}{*}{$\begin{array}{l}\text { Dari Workshop ini saya } \\
\text { mengerti bagaimana } \\
\text { cara membuat Japanese } \\
\text { Fruit Sando }\end{array}$} & Sangat Tidak Setuju & 0 & $0 \%$ \\
\hline & Tidak Setuju & 0 & $0 \%$ \\
\hline & Kurang Setuju & 0 & $0 \%$ \\
\hline & Agak Setuju & 1 & $6,7 \%$ \\
\hline & Setuju & 1 & $6,7 \%$ \\
\hline & Sangat Setuju & 13 & $86,7 \%$ \\
\hline
\end{tabular}

Hasil dari pertanyaan tersebut menunjukkan 13 orang atau setara dengan $86.7 \%$ menjawab sangat setuju, 1 orang atau setara dengan $6.7 \%$ menjawab setuju dan 1 orang atau setara dengan $6.7 \%$ menjawab cenderung setuju.

\section{Tertarik Untuk Mencoba Membuat Japanese Fruit Sando}

Tabel 12. Feedback Form

\begin{tabular}{llcc}
\hline Pertanyaan & Jawaban & Jumlah Responden & Persentase \\
\hline & Sangat Tidak Setuju & 0 & $0 \%$ \\
\cline { 2 - 4 } & Tidak Setuju & 0 & $0 \%$ \\
\cline { 2 - 4 } $\begin{array}{l}\text { Saya tertarik untuk mencoba } \\
\text { membuat Japanese Fruit Sando }\end{array}$ & Kurang Setuju & 0 & $0 \%$ \\
\cline { 2 - 4 } & Agak Setuju & 0 & $0 \%$ \\
\cline { 2 - 4 } & Setuju & 1 & $6,7 \%$ \\
\cline { 2 - 4 } & Sangat Setuju & 14 & $93,3 \%$ \\
\hline
\end{tabular}

Hasil dari pertanyaan tersebut menunjukkan menunjukkan 14 orang atau setara dengan $93.3 \%$ menjawab sangat setuju, 1 orang atau setara dengan $6.7 \%$ menjawab setuju. 
DOI: https://doi.org/10.30647/jpp.v30647/jpp.v3i2.1595

Vasco A. H. Goeltom, V. Nonot Yuliantoro, Dhana Calista Oktaviani dan Jesslyn Angriawan

\section{Ide Pembuatan Japanese Fruit Sando Membantu Untuk Berjualan}

Tabel 13. Feedback Form

\begin{tabular}{|c|c|c|c|c|}
\hline Pertanyaan & & Jawaban & Jumlah Responden & Persentase \\
\hline \multirow{6}{*}{$\begin{array}{l}\text { Ide pembuatan Japanese } \\
\text { Sando membantu } \\
\text { berjualan }\end{array}$} & \multirow{6}{*}{$\begin{array}{c}\text { Fruit } \\
\text { saya }\end{array}$} & Sangat Tidak Setuju & 0 & $0 \%$ \\
\hline & & Tidak Setuju & 0 & $0 \%$ \\
\hline & & Kurang Setuju & 1 & $6,7 \%$ \\
\hline & & Agak Setuju & 0 & $0 \%$ \\
\hline & & Setuju & 6 & $40 \%$ \\
\hline & & Sangat Setuju & 8 & $53,3 \%$ \\
\hline
\end{tabular}

Hasil dari pertanyaan tersebut menunjukkan 8 orang atau setara dengan $53.3 \%$ menjawab sangat setuju, 6 orang atau setara dengan $40 \%$ menjawab setuju dan 1 orang atau setara dengan $6.7 \%$ menjawab cenderung tidak setuju.

\section{Secara Keseluruhan, Workshop Sudah Terorganisir Dengan Baik}

Tabel 14. Feedback Form

\begin{tabular}{lllc}
\hline \multicolumn{1}{c}{ Pertanyaan } & \multicolumn{1}{c}{ Jawaban } & Jumlah Responden & Persentase \\
\hline \multirow{3}{*}{$\begin{array}{l}\text { Secara keseluruha, Workshop } \\
\text { ini sudah terorganisir dengan } \\
\text { baik }\end{array}$} & Sangat Tidak Setuju & 0 & $0 \%$ \\
\cline { 2 - 4 } & Tidak Setuju & 0 & $0 \%$ \\
\cline { 2 - 4 } & Kurang Setuju & 1 & $6,7 \%$ \\
\cline { 2 - 4 } & Agak Setuju & 0 & $0 \%$ \\
\cline { 2 - 4 } & Setuju & 1 & $6,7 \%$ \\
\cline { 2 - 4 } & Sangat Setuju & 13 & $86,7 \%$ \\
\hline
\end{tabular}

Hasil dari pertanyaan tersebut menunjukkan menunjukkan 13 orang atau setara dengan $86.7 \%$ menjawab sangat setuju, 1 orang atau setara dengan $6.7 \%$ menjawab setuju dan 1 orang atau setara dengan $6.7 \%$ menjawab cenderung tidak setuju.

\section{Penyampaian Materi Dan Sesi Tanya Jawab Sesuai Kebutuhan Peserta}

Tabel 15. Feedback Form

\begin{tabular}{lllcc}
\hline Pertanyaan & & Jawaban & Jumlah Responden & Persentase \\
\hline Anggota tim Workshop yang & Sangat Tidak Setuju & 0 & $0 \%$ \\
\cline { 3 - 5 } $\begin{array}{l}\text { terlibat dalam kegiatan ini } \\
\text { memberikan pelayanan yang baik }\end{array}$ & Tidak Setuju & 0 & $0 \%$ \\
\cline { 3 - 5 } $\begin{array}{l}\text { Penyampaian materi dan sesi } \\
\text { tanya jawab) }\end{array}$ & Sesuai kebutuhan & Kurang Setuju & 0 & $0 \%$ \\
\cline { 3 - 5 } peserta & & Setuju & 1 & $6,7 \%$ \\
\cline { 2 - 5 } & & Sangat Setuju & 2 & $13,3 \%$ \\
\hline
\end{tabular}

Hasil dari pertanyaan tersebut menunjukkan 12 orang atau setara dengan $80 \%$ menjawab sangat setuju, 2 orang atau setara dengan $13.3 \%$ menjawab setuju dan 1 orang atau setara dengan $6.7 \%$ menjawab cenderung setuju.

\section{KESIMPULAN}

Kegiatan pelatihan pembuatan Japanese Fruit Sando di SML UMKM Centre BSD City berjalan dengan baik dan lancar. Para peserta mengikuti dengan baik pemaparan materi yang dijelaskan oleh tim PKM, dapat dilihat dari jawaban post-test 
yang rata-rata dijawab dengan benar oleh para peserta PKM. Tujuan pelaksanaan kegiatan ini yaitu untuk memperkenalkan makanan-makanan jajanan yang ada di Asia Timur serta untuk memberikan ide bisnis kepada para ibu rumah tangga di SML UMKM Centre BSD City. Berdasarkan kuesioner yang telah diisi oleh para peserta dapat disimpulkan bahwa kegiatan PKM berhasil memberikan pengetahuan baru untuk mereka dan menambah wawasan baru bagi para peserta. Saran yang akan diberikan untuk pelaksanaan PKM kemudian hari adalah dianjurkan untuk membawakan materi PKM tidak hanya satu topik melainkan beberapa topik. Dan bila memungkinkan PKM dilaksanakan secara offline akan lebih baik.

\section{DAFTAR PUSTAKA}

Aykaç, E., \& Buyruk, L. (2021). Bibliometric Analysis of Researches on Street Food. Journal of Tourism and Gastronomy Studies, 9: 660-673.

Daliwu, S. (2021). Penjatuhan Pidana Denda Terhadap Pelaku Tindak Pidana Pangan. Jurnal Education and Development, 9(2), 344-352.

Febriana., \& Herlambang, S. (2020). Eksplorasi Mixed-Program (Pasar Bunga, Kuliner, Dan Taman Kota) Dalam Merancang 3 Flore Kebayoran Lama, Jakarta Selatan. Jurnal Sains, Teknologi, Urban, Perancangan, Arsitektur (Stupa), 2(2):13671382.

Nur Biduri, F., Harun, Y., Widiastuti, Yurniar Ernawati, E., Nasir, S., \& Winata, A. (2020). Pengenalan Kuliner Asia Timur kepada Masyarakat Bojong Indah III Pondok Kelapa Jakarta Timur. Laporan Kegiatan Pengabdian Kepada Masyarakat, Fakultas Sastra Universitas Darma Persada.

Prabandari, W. D., Ikpn, J., Kusir, T., Bintaro, J., \& Selatan, I. (2020). Consumer Perception about Culinary Street Food (Street Vendors) in Jalan Sabang Jakarta Pusat. International Journal of Innovative Science and Research Technology, 5(11): 359-366.

Ranka, S. (2020). How Corona Virus could Affect the Culture of Eating Special Reference to Street Food: The New Normal. IOSR Journal of Business and Management: 22(6): 1-7.

Santa, N. (2021). Amazing Asian Dessert Recipes: Mouth-Watering Sweets to Brighten up Your Table. Diakses Pada 25 Agustus 2021, dari https://www.amazon.com/Amazing-Asian-Dessert-Recipes-Mouth-Wateringebook/dp/B08RHVPM6G.

Steven, Q. A., Ching, L., \& Reid, C. (2018). Fast Food, Street Food : Western Fast Food' s Influence on Fast Service Food in China. An Honors Thesis, In The Department Of Asian And Middle Eastern Studies.

Wijanarko, A. (2020). Tantangan Industri Jasa di Indonesia Selama Pandemi COVID19. Paramadina Public Policy Review, 1-4.

Zeb, S., Hussain, S. S., \& Javed, A. (2021). Covid-19 and A Way Forward for Restaurants and Street Food Vendors. Cogent Business and Management, 8(1): $1-11$. 